\title{
Sedentary Lifestyle and High-Carbohydrate Intake are Associated with Low-Grade Chronic Inflammation in Post-Menopause: A Cross-sectional Study
}

\section{Sedentarismo e alto consumo de carboidratos associados à inflamação crônica de baixo grau na pós-menopausa: um estudo transversal}

\author{
Bruna Cherubini Alves ${ }^{1}$ Thaís Rasia da Silva ${ }^{1}$ Poli Mara Spritzer ${ }^{1,2}$ \\ ${ }^{1}$ Gynecological Endocrinology Unit, Division of Endocrinology, \\ Address for correspondence Poli Mara Spritzer, MD, PhD, Serviço de \\ Hospital de Clínicas de Porto Alegre (HCPA), Porto Alegre, RS, Brazil \\ 2 Laboratory of Molecular Endocrinology, Department of Physiology, \\ Endocrinologia, Hospital de Clínicas de Porto Alegre, Rua Ramiro \\ Barcelos, 2350, 90035-003, Porto Alegre, RS., Brazil \\ Universidade Federal do Rio Grande do Sul (UFRGS), Porto Alegre, RS, Brazil \\ (e-mail: spritzer@ufrgs.br).
}

Rev Bras Ginecol Obstet 2016;38:317-324.

\section{Abstract \\ Keywords \\ - inflammation \\ - cardiovascular disease \\ - menopause \\ - dietary pattern \\ - physical activity}

Introduction Cardiovascular disease (CVD) is the leading cause of death in post menopausal women, and inflammation is involved in the atherosclerosis process.

Purpose to assess whether dietary pattern, metabolic profile, body composition and physical activity are associated with low-grade chronic inflammation according to highsensitivity C-reactive protein (hs-CRP) levels in postmenopausal women.

Methods ninety-five postmenopausal participants, with no evidence of clinical disease, underwent anthropometric, metabolic and hormonal assessments. Usual dietary intake was assessed with a validated food frequency questionnaire, habitual physical activity was measured with a digital pedometer, and body composition was estimated by bioelectrical impedance analysis. Patients with hs-CRP $\geq 10 \mathrm{mg} / \mathrm{L}$ or using hormone therapy in the last three months before the study were excluded from the analysis. Participants were stratified according to hs-CRP lower or $\geq 3 \mathrm{mg} / \mathrm{L}$. Sedentary lifestyle was defined as walking fewer than 6 thousand steps a day. Two-tailed Student's t-test, Wilcoxon-Mann-Whitney $U$ or Chi-square $\left(\chi^{2}\right)$ test were used to compare differences between groups. A logistic regression model was used to estimate the odds ratio of variables for high hs-CRP.

Results participants with hs-CRP $\geq 3 \mathrm{mg} / \mathrm{L}$ had higher body mass index (BMI), body fat percentage, waist circumference (WC), triglycerides, glucose, and homeostasis model assessment of insulin resistance (HOMA-IR) ( $p=0.01$ for all variables) than women with hs-CRP $<3 \mathrm{mg} / \mathrm{L}$. Also, women with hs-CRP $\geq 3 \mathrm{mg} / \mathrm{L}$ had a higher glycemic load diet and lower protein intake. Prevalence of sedentary lifestyle received

April 17, 2016

accepted

May 12, 2016

published online

July 15, 2016
DOI http://dx.doi.org/

10.1055/s-0036-1584582. ISSN 0100-7203.
Copyright $\odot 2016$ by Thieme Publicações License terms

Ltda, Rio de Janeiro, Brazil
(요 (1) $\Theta \circledast$ 


\section{Resumo}

\author{
Palavras-chave \\ - inflamação \\ - doença \\ cardiovascular \\ - menopausa \\ - padrões dietéticos \\ - atividade física
}

$(p<0.01)$ and metabolic syndrome $(p<0.01)$ was higher in women with hs-CRP $\geq 3$ $\mathrm{mg} / \mathrm{L}$. After adjustment for age and time since menopause, the odds ratio for hsCRP $\geq 3 \mathrm{mg} / \mathrm{L}$ was higher for sedentary lifestyle $(4.7,95 \%$ confidence interval [ $95 \% \mathrm{Cl}$ ] 1.4-15.5) and carbohydrate intake (2.9, 95\%Cl 1.1-7.7).

Conclusions sedentary lifestyle and high-carbohydrate intake were associated with low-grade chronic inflammation and cardiovascular risk in postmenopause.

Introdução A doença cardiovascular é a principal causa de morte em mulheres na pós-menpausa e inflamação está envolvida com o processo de aterosclerose.

Objetivo avaliar se o padrão alimentar, o perfil metabólico, a composição corporal e a atividade física estão associados à inflamação crônica de baixo grau, de acordo com os níveis de proteína C-reativa (PCR-us), em mulheres na pós-menopausa.

Métodos noventa e cinco participantes pós-menopáusicas foram submetidas a avaliações antropométrica, metabólica e hormonal. A ingestão alimentar foi avaliada por meio de questionário de frequência alimentar, a atividade física habitual, com pedômetro digital, e a composição corporal, por bioimpedância elétrica. Pacientes com PCR-us $\geq 10 \mathrm{mg} / \mathrm{L}$ ou em uso de terapia hormonal nos últimos três meses antes do estudo foram excluídas. As participantes foram estratificadas de acordo PCR-us inferior ou $\geq 3 \mathrm{mg} / \mathrm{L}$. Pacientes com menos de $6 \mathrm{mil}$ passos/dia foram consideradas sedentárias. Para análise estatística foram utilizados teste $t$ de Student, Wilcoxon-MannWhitney $U$ ou Qui-quadrado $\left(\chi^{2}\right)$, além de modelo de regressão logística para estimar a razão de chances para PCR-us elevada.

Resultados participantes com PCR-us $\geq 3 \mathrm{mg} / \mathrm{L}$ apresentaram maior índice de massa corporal (IMC), percentual de gordura corporal, circunferência da cintura, triglicerídeos, glicose e índice de insulino-resistência (HOMA-IR) $(p=0,01)$ comparadas às mulheres com PCR-us $<3 \mathrm{mg} / \mathrm{L}$. O grupo PCR-us $\geq 3 \mathrm{mg} / \mathrm{L}$ apresentou uma dieta com maior carga glicêmica e menor ingestão de proteínas. A prevalência de sedentarismo e síndrome metabólica foi maior em mulheres com PCR-us $\geq 3 \mathrm{mg} / \mathrm{L}(p<0,01)$. Após ajuste para idade e tempo de menopausa, a razão de chances para PCR-us $\geq 3 \mathrm{mg} / \mathrm{L}$ foi maior nas sedentárias $(4,7$, intervalo de confiança de $95 \%[95 \% \mathrm{Cl}] 1,4-15,5)$ e com maior ingestão de carboidratos $(2,9,95 \% \mathrm{Cl} 1.1-7,7)$.

Conclusões Sedentarismo e alta ingestão de carboidratos foram associados com inflamação crônica de baixo grau e risco cardiovascular em mulheres na pósmenopausa.

\section{Introduction}

Cardiovascular disease (CVD) is still the leading cause of death among postmenopausal women worldwide. ${ }^{1,2}$ The pathophysiology of CVD is associated with atherosclerosis, a progressive process that usually begins in childhood and presents subclinical alterations or clinical manifestations from adulthood. ${ }^{3}$

Inflammation is the key mechanism in the pathogenesis of atherosclerosis. ${ }^{3,4}$ The inflammatory process associated with atherosclerosis is difficult to estimate directly. Therefore, biomarkers of inflammation have been the object of growing interest. ${ }^{3,5}$ Among the acute-phase proteins, C-reactive protein has good stability, high sensitivity, good reproducibility, and precision as such a marker. ${ }^{5}$ High-sensitivity CRP (hs(RP) is associated with cardiovascular risk factors in postmenopausal women, such as central fat distribution, insulin resistance, blood pressure and lipid profile. ${ }^{6}$
Diet is a major modifiable risk factor for $\mathrm{CVD}^{7}$ The glycemic index (GI) and glycemic load (GL), which reflect the propensity of carbohydrate to raise blood glucose levels, have gained increasing importance. ${ }^{8}$ High-GI and high-GL diets have been associated with increased risk of coronary heart disease and stroke. ${ }^{9}$

Therefore, the aim of the present study was to assess whether diet, metabolic profile, body composition and physical activity are associated with low-grade chronic inflammation, as determined by hs-CRP levels among a sample of postmenopausal women.

\section{Methods}

\section{Subjects}

This cross-sectional study was performed at Hospital de Clínicas de Porto Alegre, Brazil, from October 2010 to 
February 2012. Participants were recruited by advertisement in a local newspaper and radio station. ${ }^{10}$ Postmenopausal women aged 45-65 years and presenting with at least 1 year of amenorrhea and follicle-stimulating hormone (FSH) levels $>35 \mathrm{mIU} / \mathrm{mL}$ were included. The exclusion criteria were use of hormone therapy or antiinflammatory agents (current or in the preceding 3 months), untreated thyroid disease, previous diagnosis of cardiovascular disease, diabetes mellitus or rheumatic diseases, and smoking. The study protocol was approved by the local Research Ethics Committee, and written informed consent was obtained from every subject.

\section{Study Protocol}

All participants completed a questionnaire about their sociodemographic characteristics. Blood pressure was measured using a digital sphygmomanometer (HEM-742, Omron, Rio de Janeiro, Brazil) after 10 minutes of rest, with participants in the sitting position. Hypertension was defined as a blood pressure $\geq 140 / 90 \mathrm{~mm} \mathrm{Hg}$ or by the regular use of antihypertensive drugs.

Anthropometric measurements were obtained in duplicate and included body weight, height, and waist circumference (WC). ${ }^{11,12}$ Body mass index (BMI, $\mathrm{kg} / \mathrm{m}^{2}$ ) was calculated. Body composition was assessed by bioelectrical impedance analysis (BIA) (Inbody230, Biospace Inc., Los Angeles, USA). All blood samples were obtained between 8 and $10 \mathrm{Am}$, after a 12-hour fast. Metabolic syndrome was diagnosed as defined in the Joint Scientific Statement. ${ }^{13}$ Participants were stratified in two groups according to hsCRP as $<3 \mathrm{mg} / \mathrm{L}$ or $\geq 3 \mathrm{mg} / \mathrm{L}$.

\section{Assays}

Total cholesterol, high-density lipoprotein cholesterol (HDL-c), and triglycerides (TG) were determined by colorimetric-enzymatic methods (Bayer 1800 Advia System, Mannheim, Germany), with intra- and interassay coefficients of variation $(\mathrm{CV})<3 \%$. Glucose was quantitated by the hexokinase method (Advia 1800, Mannheim, Germany), with an intra- and interassay CV $<3.4 \%$. A validated high-sensitivity nephelometric method (Dade Behring Marburg, Marburg, Germany) was used for hs-CRP analysis in stored specimens, with a sensitivity of $0.17 \mathrm{mg} / \mathrm{L}$ and intra- and interassay CVs of 4.4 and $5.7 \%$ respectively. Individual results below the limit of sensitivity of the test $(\leq 0.17)$ were considered as equal to $0.17 \mathrm{mg} / \mathrm{L}$ for statistical analysis. Follicle- stimulating hormone (FSH) levels were measured by chemiluminescence immunoassay (CLIA) (Centaur XP, Mannheim, Germany). Serum insulin levels were measured using CLIA (Centaur XP), with a sensitivity of $0.200 \mu \mathrm{IU} / \mathrm{mL}$ and intra- and interassay CVs of 2.0 and $4.3 \%$ respectively. Low-density lipoprotein cholesterol (LDL-c) was calculated using the Friedewald formula. The homeostasis model assessment of insulin resistance (HOMA-IR) index was calculated by multiplying insulin $(\mu \mathrm{IU} / \mathrm{mL})$ by glucose $(\mathrm{mmol} / \mathrm{L})$ and dividing this product by 22.5 , and the lipid accumulation product (LAP) was calculated using the formula: $\mathrm{LAP}=(\mathrm{WC}-58) \times \mathrm{TG}^{14,15}$

\section{Dietary Assessment}

Usual dietary intake in the last month before the study was assessed with a validated food frequency questionnaire consisting of 120 items. ${ }^{16}$ Nutritional composition was calculated using the Brazilian Table of Food Composition (NEPAUNICAMP, Campinas, Brazil), except for vitamin D, E, and A, which were assessed using the United States Department of Agriculture (USDA) National Standard Reference Database. The glycemic index (GI) and GL were calculated according to standards proposed by the Food and Agriculture Organization (FAO) from the International Tables of Glycemic Index and Glycemic Load Values, with glucose used as reference. ${ }^{17}$

\section{Physical Activity Assessment}

Habitual physical activity was assessed with a digital pedometer(BP 148, Tech Line, São Paulo, Brazil). The device was configured individually according to weight $(\mathrm{kg})$ and individual step length, and worn for 6 consecutive days, providing a weekly average number of steps. Subjects were recommended not to change their physical activity habits during the study. Those who walked fewer than 6 thousand steps a day were considered inactive. ${ }^{18,19}$

\section{Statistical Analyses}

The healthy group (hs-CRP $<3 \mathrm{mg} / \mathrm{L}$ ) and the group presenting low-grade chronic inflammation (hs-CRP $\geq 3 \mathrm{mg} / \mathrm{L}$ ) were defined according to the National Academy of Clinical Biochemistry Laboratory Medicine Practice Guidelines. ${ }^{20} \mathrm{~Pa}$ tients with hs-CRP $\geq 10 \mathrm{mg} / \mathrm{L}$ were excluded from analysis, because this value might be indicative of acute inflammation. ${ }^{20}$ Results are presented as mean \pm standard deviation (SD) or median and interquartile range for normally and nonnormally distributed variables respectively. The two-tailed Student's t-test or the Wilcoxon-Mann-Whitney U test were used to compare the differences between means of parametric and nonparametric data respectively. The Chi-square $\left(\chi^{2}\right)$ test was calculated for comparisons of dichotomous variables. A logistic regression model was used to estimate the odds ratio of different variables for high hs-CRP, which was considered the dependent variable. All analyses were performed in the SPSS 19.0 environment (SPSS Inc., Chicago, IL, USA). Data were deemed significant at $p<0.05$.

\section{Results}

Out of 119 volunteers, 5 were excluded for diabetes mellitus, 1 for heart disease, 1 for hyperthyroidism, 2 for untreated hypothyroidism, 2 for breast cancer, and 1 for premenopausal status. An additional 3 participants dropped out because they were unable to commit to the study (no free time for blood collection), and 9 had hs-CRP levels $\geq 10 \mathrm{mg} / \mathrm{L}$. Thus, 95 women were enrolled to the study.

- Table 1 shows demographic, metabolic and hormonal profiles as well as body composition-related variables of participants stratified by hs-CRP levels ( $<3$ or $\geq 3 \mathrm{mg} / \mathrm{L}$ ). The mean age of the sample was $54.7 \pm 4.8$ years, and the mean duration of menopause was $6.5 \pm 4.0$ years. Age, duration of menopause, race and educational attainment 
Table 1 Characteristics of 95 postmenopausal women stratified by hs-CRP level

\begin{tabular}{|c|c|c|c|c|}
\hline & Overall & $<3 \mathrm{mg} / \mathrm{dL}$ & $\geq 3 \mathrm{mg} / \mathrm{dL}$ & $p$-value \\
\hline & $\mathbf{n}=95$ & $\mathrm{n}=72$ & $\mathrm{n}=23$ & \\
\hline Age $\left(\right.$ years) ${ }^{a}$ & $54.7 \pm 4.8$ & $54.7 \pm 5.0$ & $55.3 \pm 4.1$ & 0.58 \\
\hline Time since menopause (years) $^{\mathrm{b}}$ & $\begin{array}{l}5.0 \\
(2.0-10.0)\end{array}$ & $\begin{array}{l}5.0 \\
(3.0-10.0)\end{array}$ & $\begin{array}{l}4.5 \\
(2.9-8.0)\end{array}$ & 0.46 \\
\hline Years at school ${ }^{\mathrm{b}}$ & $\begin{array}{l}8.0 \\
(5.0-11.0)\end{array}$ & $\begin{array}{l}8.0 \\
(5.0-11.0)\end{array}$ & $\begin{array}{l}8.0 \\
(5.0-11.0)\end{array}$ & 0.79 \\
\hline White, $\mathrm{n}(\%)^{\mathrm{c}}$ & $\begin{array}{l}83 \\
(87.4) \\
\end{array}$ & $\begin{array}{l}61 \\
(84.7) \\
\end{array}$ & $\begin{array}{l}22 \\
(95.6) \\
\end{array}$ & 0.28 \\
\hline BMI $\left(\mathrm{kg} / \mathrm{m}^{2}\right)^{\mathrm{b}}$ & $\begin{array}{l}26.2 \\
(23.8-29.1)\end{array}$ & $\begin{array}{l}25.3 \\
(23.1-28.0)\end{array}$ & $\begin{array}{l}29.9 \\
(25.0-32.0)\end{array}$ & $<0.01$ \\
\hline$W C(\mathrm{~cm})^{\mathrm{b}}$ & $\begin{array}{l}84.5 \\
(78.0-91.0)\end{array}$ & $\begin{array}{l}83.0 \\
(76.2-87.4)\end{array}$ & $\begin{array}{l}94.0 \\
(89.0-101.5)\end{array}$ & $<0.01$ \\
\hline Lean mass $(\mathrm{kg})^{\mathrm{b}}$ & $\begin{array}{l}23.4 \\
(8.5-33.1)\end{array}$ & $\begin{array}{l}22.6 \\
(21.1-25.4)\end{array}$ & $\begin{array}{l}23.9 \\
(21.3-26.8)\end{array}$ & 0.31 \\
\hline Fat mass $(\mathrm{kg})^{\mathrm{b}}$ & $\begin{array}{l}23.9 \\
(36.0-120.0)\end{array}$ & $\begin{array}{l}21.3 \\
(17.0-26.5)\end{array}$ & $\begin{array}{l}30.3 \\
(24.0-34.4)\end{array}$ & $<0.01$ \\
\hline$\%$ Fat mass ${ }^{\mathrm{a}}$ & $35.4 \pm 7.0$ & $33.6 \pm 6.6$ & $40.9 \pm 5.0$ & $<0.01$ \\
\hline $\mathrm{TC}(\mathrm{mg} / \mathrm{dL})^{\mathrm{a}}$ & $217.7 \pm 35.5$ & $216.9 \pm 36.8$ & $220.4 \pm 31.7$ & 0.38 \\
\hline HDL-c $(\mathrm{mg} / \mathrm{dL})^{\mathrm{b}}$ & $\begin{array}{l}53.0 \\
(45.0-63.0)\end{array}$ & $\begin{array}{l}53.0 \\
(46.2-64.7)\end{array}$ & $\begin{array}{l}48.0 \\
(41.0-52.0)\end{array}$ & 0.02 \\
\hline LDL-c $(\mathrm{mg} / \mathrm{dL})^{\mathrm{b}}$ & $\begin{array}{l}137.4 \\
(117.3-159.0)\end{array}$ & $\begin{array}{l}135.9 \\
(116.8-156.7)\end{array}$ & $\begin{array}{l}143.6 \\
(122.9-161.2)\end{array}$ & 0.45 \\
\hline $\mathrm{TG}(\mathrm{mg} / \mathrm{dL})^{\mathrm{b}}$ & $\begin{array}{l}98.0 \\
(73.0-146.0)\end{array}$ & $\begin{array}{l}88.5 \\
(72.0-138.5)\end{array}$ & $\begin{array}{l}134.0 \\
(98.0-208.0)\end{array}$ & 0.01 \\
\hline Glucose $(\mathrm{mg} / \mathrm{dL})^{a}$ & $92.8 \pm 8.4$ & $91.5 \pm 7.5$ & $97.1 \pm 9.6$ & $<0.01$ \\
\hline Insulin $(\mu U \mathrm{I} / \mathrm{mL})^{\mathrm{b}}$ & $\begin{array}{l}8.8 \\
(5.9-13.9)\end{array}$ & $\begin{array}{l}7.9 \\
(5.7-12.1)\end{array}$ & $\begin{array}{l}14.7 \\
(8.1-19.5)\end{array}$ & $<0.01$ \\
\hline HOMA-IR & $\begin{array}{l}2.0 \\
(1.3-3.3)\end{array}$ & $\begin{array}{l}1.8 \\
(1.3-2.8)\end{array}$ & $\begin{array}{l}3.2 \\
(1.7-4.5)\end{array}$ & 0.01 \\
\hline $\mathrm{LAP}^{\mathrm{b}}$ & $\begin{array}{l}30.8 \\
(17.8-45.9)\end{array}$ & $\begin{array}{l}25.2 \\
(17.3-38.1)\end{array}$ & $\begin{array}{l}45.9 \\
(32.7-65.3)\end{array}$ & $<0.01$ \\
\hline Hypertension (\%) ${ }^{c}$ & $37(39 \%)$ & $27(37 \%)$ & $10(43 \%)$ & 0.67 \\
\hline Metabolic syndrome $^{c}$ & $18(19 \%)$ & $8(11 \%)$ & $10(43 \%)$ & $<0.01$ \\
\hline Mean steps a day ${ }^{b}$ & $\begin{array}{l}5,258 \\
(3,662-8,227)\end{array}$ & $\begin{array}{l}6,069 \\
(4,315-8,394)\end{array}$ & $\begin{array}{l}3,961 \\
(2,310-5,962)\end{array}$ & $<0.01$ \\
\hline
\end{tabular}

Abbreviations: BMI, body mass index; HDL-c, HDL cholesterol; HOMA-IR, homeostasis model assessment of insulin resistance; LAP, lipid accumulation product; LDL-c, LDL cholesterol; n, number; TC, total cholesterol; TG, triglycerides; WC, waist circumference.

astudent's t-test,

${ }^{b}$ Mann-Whitney-Wilcoxon U test,

${ }^{c}$ Chi-square Test.

were similar in both groups. However, the hs-CRP $<3 \mathrm{mg} / \mathrm{L}$ group exhibited lower BMI, WC, body fat percentage, body fat mass in comparison with the hs-CRP $\geq 3 \mathrm{mg} / \mathrm{L}$ group $(p<0.01)$. The median number of steps walked per day was greater in women with lower levels of hs-CRP, and the prevalence of sedentary lifestyle was lower (49\% versus $78 \%$, $p=0.02)$. The hs-CRP $<3 \mathrm{mg} / \mathrm{L}$ group had higher HDL-c levels and lower TG, fasting glucose, insulin, HOMA-IR, and LAP in comparison with the hs-CRP $\geq 3 \mathrm{mg} / \mathrm{L}$ group. Metabolic syndrome was also more frequent in the hs-CRP $\geq 3 \mathrm{mg}$ / L group.
Regarding dietary intake (-Table 2 ), there was a lower energy intake from carbohydrate and higher from protein in the hs-CRP $<3 \mathrm{mg} / \mathrm{L}$ group. Energy intake from fat was similar between groups, and while saturated fat was slightly higher in the the hs-CRP $<3 \mathrm{mg} / \mathrm{L}$ group, values were in accordance with reference ranges. Dietary GL was lower in the hs-CRP $<3 \mathrm{mg} / \mathrm{L}$ group, and GI was similar between the groups. Vitamin E intake was markedly below the reference values in both groups.

After adjustment for age and duration of menopause, the odds ratio for hs-CRP $\geq 3 \mathrm{mg} / \mathrm{L}$ was higher with sedentary 
Sedentarism and High-Carbohydrate Intake on Low-Grade Chronic Inflammation in Post-Menopause Alves et al. 321

Table 2 Dietary intake in 95 postmenopausal women stratified by hs-CRP level

\begin{tabular}{|c|c|c|c|c|}
\hline Daily intake & $<3 \mathrm{mg} / \mathrm{dL}$ & $\geq 3 \mathrm{mg} / \mathrm{dL}$ & \multirow[t]{2}{*}{$p$-value } & \multirow[t]{2}{*}{ Reference range } \\
\hline & $\mathrm{n}=72$ & $\mathrm{n}=23$ & & \\
\hline Total Kcal $^{\mathrm{b}}$ & $\begin{array}{l}1,716.8 \\
(1,418.8-2,217.3)\end{array}$ & $\begin{array}{l}2,053.3 \\
(1,415.0-2,584.7)\end{array}$ & 0.18 & - \\
\hline \% Carbohydrate Kcal ${ }^{\mathrm{b}}$ & $\begin{array}{l}55.4 \\
(50.4-58.4)\end{array}$ & $\begin{array}{l}61.3 \\
(55.9-65.1)\end{array}$ & $<0.01$ & $45-65^{*}$ \\
\hline Carbohydrate $(\mathrm{g})^{\mathrm{b}}$ & $\begin{array}{l}244.5 \\
(186.6-309.0)\end{array}$ & $\begin{array}{l}295.4 \\
(202.3-397.3)\end{array}$ & 0.06 & $130^{*}$ \\
\hline Glycemic load $(\mathrm{g})^{\mathrm{b}}$ & $\begin{array}{l}128.4 \\
(95.4-153.3)\end{array}$ & $\begin{array}{l}152.0 \\
(111.5-197.3)\end{array}$ & 0.04 & $<120^{\#}$ \\
\hline Glycemic index (\%) $^{\mathrm{b}}$ & $\begin{array}{l}55.5 \\
(51.8-58.4)\end{array}$ & $\begin{array}{l}55.9 \\
(52.7-58.3)\end{array}$ & 0.72 & ND \\
\hline Fiber $(g)^{b}$ & $\begin{array}{l}25.3 \\
(19.3-34.1)\end{array}$ & $\begin{array}{l}28.6 \\
(20.8-43.3)\end{array}$ & 0.14 & $25^{*}$ \\
\hline$\%$ Protein $\mathrm{Kcal}^{\mathrm{a}}$ & $16.9 \pm 2.7$ & $15.1 \pm 3.5$ & 0.03 & $10-35^{*}$ \\
\hline Protein $(\mathrm{g})^{\mathrm{b}}$ & $\begin{array}{l}79.1 \\
(57.5-90.8)\end{array}$ & $\begin{array}{l}70.4 \\
(64.6-94.5)\end{array}$ & 0.65 & $46^{*}$ \\
\hline$\% \mathrm{Fat} \mathrm{Kcal}^{\mathrm{a}}$ & $24.1 \pm 5.6$ & $21.6 \pm 5.3$ & 0.06 & $20-35^{*}$ \\
\hline Fat $(g)^{b}$ & $\begin{array}{l}48.3 \\
(32.0-61.5)\end{array}$ & $\begin{array}{l}48.4 \\
(37.3-54.2)\end{array}$ & 0.91 & ND \\
\hline SFA (\%) ${ }^{\mathrm{a}}$ & $7.1 \pm 2.1$ & $6.0 \pm 1.6$ & 0.03 & $<10 \%^{\mathrm{d}}$ \\
\hline PUFA (\%) & $3.3 \pm 1.0$ & $3.3 \pm 1.0$ & 0.74 & ND \\
\hline MUFA (\%) & $\begin{array}{l}7.0 \\
(5.8-8.8)\end{array}$ & $\begin{array}{l}6.6 \\
(5.1-7.4)\end{array}$ & 0.10 & ND \\
\hline Cholesterol $(\mathrm{mg})^{\mathrm{b}}$ & $\begin{array}{l}183.2 \\
(132.1-254.6)\end{array}$ & $\begin{array}{l}210.1 \\
(108.1-255.9)\end{array}$ & 0.98 & $<300^{\mathrm{b}}$ \\
\hline Calcium $(\mathrm{mg})^{\mathrm{b}}$ & $\begin{array}{l}721.1 \\
(509.9-999.2)\end{array}$ & $\begin{array}{l}794.1 \\
(462.8-944.8)\end{array}$ & 0.73 & $1,200^{*}$ \\
\hline Magnesium $(\mathrm{mg})^{\mathrm{b}}$ & $\begin{array}{l}238.9 \\
(190.0-315.4)\end{array}$ & $\begin{array}{l}289.0 \\
(195.8-387.5)\end{array}$ & 0.19 & $320^{*}$ \\
\hline $\operatorname{Iron}(\mathrm{mg})^{\mathrm{b}}$ & $\begin{array}{l}8.2 \\
(6.4-11.4)\end{array}$ & $\begin{array}{l}10.6 \\
(6.7-14.1)\end{array}$ & 0.12 & $8^{*}$ \\
\hline Zinc $(m g)^{b}$ & $\begin{array}{l}7.9 \\
(5.9-9.7)\end{array}$ & $\begin{array}{l}8.0 \\
(6.3-9.8)\end{array}$ & 0.72 & $8^{*}$ \\
\hline Sodium $(\mathrm{mg})^{\text {a }}$ & $\begin{array}{l}1,785.8 \\
(1,415.8-2,204.6)\end{array}$ & $\begin{array}{l}1,839.2 \\
(1,564.1-2,448.7)\end{array}$ & 0.22 & $<1,500^{*}$ \\
\hline Selenium $(\mu \mathrm{g})^{\mathrm{b}}$ & $\begin{array}{l}88.9 \\
(64.5-111.9)\end{array}$ & $\begin{array}{l}91.3 \\
(71.6-106.8)\end{array}$ & 0.82 & $55^{*}$ \\
\hline Folate $(\mu g)^{b}$ & $\begin{array}{l}490.1 \\
(361.1-645.4)\end{array}$ & $\begin{array}{l}480.7 \\
(406.1-947.6)\end{array}$ & 0.47 & $400^{*}$ \\
\hline Vitamin $D(\mu \mathrm{g})^{\mathrm{b}}$ & $\begin{array}{l}4.6 \\
(2.4-10.6)\end{array}$ & $\begin{array}{l}2.7 \\
(1.9-7.1)\end{array}$ & 0.13 & $10-15^{*}$ \\
\hline Vitamin B12 $(\mu \mathrm{g})^{\mathrm{b}}$ & $\begin{array}{l}4.4 \\
(3.1-5.7)\end{array}$ & $\begin{array}{l}3.2 \\
(2.2-4.2)\end{array}$ & 0.07 & $2.4^{*}$ \\
\hline Vitamin $\mathrm{E}(\mathrm{mg})^{\mathrm{b}}$ & $\begin{array}{l}3.5 \\
(2.5-4.7)\end{array}$ & $\begin{array}{l}4.8 \\
(2.9-6.0)\end{array}$ & 0.04 & $15^{*}$ \\
\hline Vitamin C $(\mathrm{mg})^{\mathrm{b}}$ & $\begin{array}{l}157.1 \\
(106.7-272.0)\end{array}$ & $\begin{array}{l}207.6 \\
(114.7-478.4)\end{array}$ & 0.33 & $75^{*}$ \\
\hline Vitamin A $(\mu \mathrm{g})^{\mathrm{b}}$ & $\begin{array}{l}699.7 \\
(451.3-1,170.8)\end{array}$ & $\begin{array}{l}859.2 \\
(364.6-1,747.1)\end{array}$ & 0.47 & $700^{*}$ \\
\hline
\end{tabular}

Abbreviations: Kcal, kilocalories; MUFA, monounsaturated fatty acid; n, number; PUFA, polyunsaturated fatty acid; SFA, saturated fatty acid.

${ }^{\mathrm{a} S}$ Student's t-test,

${ }^{\mathrm{b}}$ Mann-Whitney-Wilcoxon $U$ test, ${ }^{\mathrm{c}}$ Chi-square Test.

*Institute of Medicine, ${ }^{21}$

${ }^{\#}$ Atkinson et al. ${ }^{17}$;

d Brazilian Society for Cardiology and Brazilian Menopause Association Guideline on the Prevention of Cardiovascular Disease in Menopausal Women and the Influence of Hormone Therapy, 2008. ${ }^{22}$ 
Table 3 Odds ratios for hs-CRP $\geq 3 \mathrm{mg} / \mathrm{L}$

\begin{tabular}{|l|l|l|l|}
\hline Variable & OR & 95\% Cl & -value $^{\text {a }}$ \\
\hline \% Carbohydrate Kcal $(>55)$ & 2.9 & $1.1-7.7$ & 0.03 \\
\hline Glycemic load $(>120 \mathrm{~g})^{\mathrm{b}}$ & 1.8 & $0.6-5.0$ & 0.30 \\
\hline Sedentary lifestyle $(<6,000$ steps/day) & 4.7 & $1.4-15.5$ & 0.01 \\
\hline Waist Circumference $(\geq 88 \mathrm{~cm})^{\mathrm{c}}$ & 13.6 & $3.9-47.0$ & $<0.01$ \\
\hline \% Body fat & \\
\hline
\end{tabular}

Abbreviations: $\mathrm{Cl}$, confidence interval; Kcal, kilocalories; OR, odds ratio.

a Logistic regression adjusted for age and time since menopause;

bInternational Tables of Glycemic Index and Glycemic Load Values: $2008^{17}$;

'Waist circumference $\geq 88 \mathrm{~cm}^{13}$;

d\% Body fat $\geq 34 \%$ for subjects aged $40-59$ years and $\geq 36 \%$ for subjects aged $\geq 60$ years. ${ }^{23}$

lifestyle, body fat percentage, WC ( $>88 \mathrm{~cm}$ ), and carbohydrate intake above $55 \%$ of total calories, that was the median of this sample; however, GL (>120 g) did not influence the odds ratio for increased hs-CRP (-Table 3 ).

\section{Discussion}

In the present study, a sample of postmenopausal women from Southern Brazil presenting no evidence of clinical disease was stratified according to the presence or absence of low-grade inflammation as a non-conventional marker for cardiovascular risk. Those with hs-CRP levels $<3 \mathrm{mg} / \mathrm{L}$ had better anthropometric, metabolic, and hormonal profiles than women with hs-CRP levels $\geq 3 \mathrm{mg} / \mathrm{L}$. Sedentary lifestyle and high-carbohydrate dietary intake were associated with central adiposity and metabolic syndrome, and contributed to low-grade chronic inflammation and risk of CVD in this sample, even after adjustment for potential confounders, including age and duration of menopause.

We observed an association between hs-CRP, body fat, and WC. These results corroborate data described in previous studies. ${ }^{6,24}$ In fact, adipocyte hypertrophy can cause hypoxia, stimulating the activation of intracellular NF- $\mathrm{BB}$, which plays a key role in regulating immune response and induces production of tumor necrosis factor- $\alpha$ (TNF- $\alpha$ ) and interleukins (IL) and, consequently, an increase in hs-CRP. ${ }^{20,24}$ This is the possible mechanism for increased levels of hs-CRP and inflammatory cytokines, such as IL- 6 and TNF- $\alpha$, among obese individuals, and may explain why these increases correlate positively with BMI. ${ }^{25}$

Studies with postmenopausal women have also shown an increased prevalence of insulin resistance, which is related to an adverse profile of weight and body fat distribution. ${ }^{11,26,27}$ In the present study, beyond higher circulating concentrations of glucose and insulin, as well as HOMA-IR, we found a higher LAP index in women with hs-CRP $\geq 3 \mathrm{mg} / \mathrm{L}$. These data extend previous results obtained by our research group, in which postmenopausal women stratified by LAP $>34.5$ also had higher levels of hs-CRP, suggesting an increased risk of cardiovascular disease. $^{14}$

Regarding lipoprotein metabolism, we observed an association of hs-CRP $\geq 3 \mathrm{mg} / \mathrm{L}$ with lower HDL-c and higher
TG levels, but not with total cholesterol and LDL-c levels. These changes may be related to insulin resistance, which was more prevalent in the hs-CRP $\geq 3 \mathrm{mg} / \mathrm{L}$ group. A similar result was observed by Moreto et al, ${ }^{28}$ who reported higher levels of HDL-c and lower levels of TG in Brazilian adults with hs-CRP $<3 \mathrm{mg} / \mathrm{L}$ in comparison to adults with hsCRP $>3 \mathrm{mg} / \mathrm{L}$.

Being physically active (in this study, defined as walking $\geq 6$ thousand steps per day) was inversely associated with hs-CRP levels, confirming the results of studies with younger ${ }^{29}$ or obese women populations ${ }^{30}$ that also reported an inverse relationship between inflammation and physical activity. The mechanisms involved with the beneficial effect of exercise seem to be related to the cytokines produced by muscle cells, which could exert a protecting role against chronic diseases associated with low-grade inflammation, including improvement on endothelial function and nitric oxide synthesis. ${ }^{31}$

In the present study, while no difference in total energy intake was found between groups, women with hs-CRP levels $\geq 3 \mathrm{mg} / \mathrm{L}$ consumed more carbohydrates and had a higher GL. Carbohydrate is the main dietary component affecting insulin secretion and postprandial glycemia. ${ }^{8}$ High-GL diets are associated with compensatory hyperinsulinemia, lipid metabolic disorders, and they induce inflammation owing to excess cellular glucose concentrations. ${ }^{32-34}$ A meta-analysis with observational studies shows that low-GL diets are independently associated with a reduced risk of chronic diseases, and supports the hypothesis that higher postprandial glycaemia is a universal mechanism for disease progression.

In turn, in our study, participants with hs-CRP levels $\geq 3$ $\mathrm{mg} / \mathrm{L}$ consumed a diet that was slightly lower in protein. $\mathrm{Hu}$ $(2005)^{35}$ suggests that there is a potential beneficial effect of replacing high-GI refined carbohydrates with protein to reduce cardiovascular risk. ${ }^{35}$

The strengths of our study include providing data from postmenopausal women with no evidence of clinical diseases. The limitation of the study is that, because of its design, we could not establish whether a causal relationship exists between dietary patterns - specifically, a higher intake of carbohydrates and a higher GL - and higher risk of CVD in postmenopausal women. Thus, further longitudinal studies or randomized clinical trials are needed to test this hypothesis. 
In conclusion, in this sample of postmenopausal women, hs-CRP levels $<3 \mathrm{mg} / \mathrm{L}$ were associated with better anthropometric, metabolic, and hormonal profiles, and a lower prevalence of the metabolic syndrome than hs-CRP levels $\geq 3$ $\mathrm{mg} / \mathrm{L}$. Sedentary lifestyle and carbohydrate intake accounting for more than $55 \%$ of total energy intake were associated with higher body fat percentage and larger WC, as well as a higher odds ratio for cardiovascular risk, as stratified by hsCRP $\geq 3 \mathrm{mg} / \mathrm{L}$.

\section{Conflict of Interest}

The authors declare no conflict of interest.

\section{Acknowledgments}

This work was supported by grants from Conselho Nacional de Desenvolvimento Científico e Tecnológico (CNPq INCT 573747/2008-3) and Fundo de Apoio à Pesquisa do Hospital de Clínicas de Porto Alegre (FIPE-HCPA 10-0544). The funding sources were not involved in the study design, in the collection, analysis and interpretation of data, in the writing of the report, or in the decision to submit the paper for publication.

\section{References}

1 Mozaffarian D, Benjamin EJ, Go AS, et al; Writing Group Members; American Heart Association Statistics Committee; Stroke Statistics Subcommittee. Executive summary: heart disease and stroke statistics - 2016 update: a report from the American Heart Association. Circulation 2016;133(4):447-454

2 Jones R, Hardy R, Sattar N, et al; NSHD Scientific and Data Collection Teams. Novel coronary heart disease risk factors at 60-64 years and life course socioeconomic position: the 1946 British birth cohort. Atherosclerosis 2015;238(1):70-76

3 Golia E, Limongelli G, Natale F, et al. Inflammation and cardiovascular disease: from pathogenesis to therapeutic target. Curr Atheroscler Rep 2014;16(9):435

4 Steyers CM III, Miller FJ Jr. Endothelial dysfunction in chronic inflammatory diseases. Int J Mol Sci 2014;15(7):11324-11349

5 Stoner L, Lucero AA, Palmer BR, Jones LM, Young JM, Faulkner J. Inflammatory biomarkers for predicting cardiovascular disease. Clin Biochem 2013;46(15):1353-1371

6 Piché ME, Lemieux S, Weisnagel SJ, Corneau L, Nadeau A, Bergeron J. Relation of high-sensitivity C-reactive protein, interleukin-6, tumor necrosis factor-alpha, and fibrinogen to abdominal adipose tissue, blood pressure, and cholesterol and triglyceride levels in healthy postmenopausal women. Am J Cardiol 2005;96(1):92-97

7 Stampfer MJ, Hu FB, Manson JE, Rimm EB, Willett WC. Primary prevention of coronary heart disease in women through diet and lifestyle. N Engl J Med 2000;343(1):16-22

8 Huffman KM, Orenduff MC, Samsa GP, Houmard JA, Kraus WE, Bales CW. Dietary carbohydrate intake and high-sensitivity Creactive protein in at-risk women and men. Am Heart J 2007; 154(5):962-968

9 Fan J, Song Y, Wang Y, Hui R, Zhang W. Dietary glycemic index, glycemic load, and risk of coronary heart disease, stroke, and stroke mortality: a systematic review with meta-analysis. PLoS ONE 2012;7(12):e52182

10 Silva TR, Franz R, Maturana MA, Spritzer PM. Associations between body composition and lifestyle factors with bone mineral density according to time since menopause in women from Southern Brazil: a cross-sectional study. BMC Endocr Disord 2015;15:71

11 Donato GB, Fuchs SC, Oppermann K, Bastos C, Spritzer PM. Association between menopause status and central adiposity measured at different cutoffs of waist circumference and waistto-hip ratio. Menopause 2006;13(2):280-285

12 Toscani M, Migliavacca R, Sisson de Castro JA, Spritzer PM. Estimation of truncal adiposity using waist circumference or the sum of trunk skinfolds: a pilot study for insulin resistance screening in hirsute patients with or without polycystic ovary syndrome. Metabolism 2007;56(7):992-997

13 Alberti KG, Eckel RH, Grundy SM, et al; International Diabetes Federation Task Force on Epidemiology and Prevention; National Heart, Lung, and Blood Institute; American Heart Association; World Heart Federation; International Atherosclerosis Society; International Association for the Study of Obesity. Harmonizing the metabolic syndrome: a joint interim statement of the International Diabetes Federation Task Force on Epidemiology and Prevention; National Heart, Lung, and Blood Institute; American Heart Association; World Heart Federation; International Atherosclerosis Society; and International Association for the Study of Obesity. Circulation 2009;120(16):1640-1645

14 Maturana MA, Moreira RM, Spritzer PM. Lipid accumulation product (LAP) is related to androgenicity and cardiovascular risk factors in postmenopausal women. Maturitas 2011;70(4): 395-399

15 Wiltgen D, Benedetto IG, Mastella LS, Spritzer PM. Lipid accumulation product index: a reliable marker of cardiovascular risk in polycystic ovary syndrome. Hum Reprod 2009;24(7): 1726-1731

16 Zanolla AF, Olinto MT, Henn RL, Wahrlich V, Anjos LA. [Assessment of reproducibility and validity of a food frequency questionnaire in a sample of adults living in Porto Alegre, Rio Grande do Sul State, Brazil]. Cad Saude Publica 2009;25(4):840-848 Portuguese

17 Atkinson FS, Foster-Powell K, Brand-Miller JC. International tables of glycemic index and glycemic load values: 2008. Diabetes Care 2008;31(12):2281-2283

18 Colpani V, Oppermann K, Spritzer PM. Association between habitual physical activity and lower cardiovascular risk in premenopausal, perimenopausal, and postmenopausal women: a population-based study. Menopause 2013;20(5):525-531

19 Graff SK, Alves BC, Toscani MK, Spritzer PM. Benefits of pedometer-measured habitual physical activity in healthy women. Appl Physiol Nutr Metab 2012;37(1):149-156

20 Myers GL, Christenson RH, Cushman M, et al; NACB LMPG Committee Members. National Academy of Clinical Biochemistry Laboratory Medicine Practice guidelines: emerging biomarkers for primary prevention of cardiovascular disease. Clin Chem 2009;55(2):378-384

21 Otten JJ, Hellwig JP, Meyers LD. Institute of Medicine. Dietary reference intakes: the essential guide to nutrient requirements. Washington (DC): National Academies Press; 2006

22 Fernandes CE, Pinho-Neto JSL, Gebara OCE. [I Brazilian Society for Cardiology and Brazilian Menopause Association Guideline on the Prevention of Cardiovascular Disease in Menopausal Women and the Influence of Hormone Therapy]. Arq Bras Cardiol 2008;91(1, Suppl 1):1-23

23 National Institutes of Health. Clinical Guidelines on the identification, evaluation, and treatment of overweight and obesity in adults: the evidence report. Obes Res 1998;6(Suppl 2): 51S-209S

24 Perry CD, Alekel DL, Ritland LM, et al. Centrally located body fat is related to inflammatory markers in healthy postmenopausal women. Menopause 2008;15(4 Pt 1):619-627

25 Bastard JP, Jardel C, Bruckert E, et al. Elevated levels of interleukin 6 are reduced in serum and subcutaneous adipose tissue of obese 
women after weight loss. J Clin Endocrinol Metab 2000;85(9): 3338-3342

26 dos Santos RE, Aldrighi JM, Lanz JR, Ferezin PC, Marone MM. Relationship of body fat distribution by waist circumference, dual-energy X-ray absorptiometry and ultrasonography to insulin resistance by homeostasis model assessment and lipid profile in obese and non-obese postmenopausal women. Gynecol Endocrinol 2005;21(5):295-301

27 Franz R, Maturana MA, Magalhães JA, Moraes RS, Spritzer PM. Central adiposity and decreased heart rate variability in postmenopause: a cross-sectional study. Climacteric 2013;16(5): 576-583

28 Moreto F, de Oliveira EP, Manda RM, et al. Pathological and behavioral risk factors for higher serum C-reactive protein concentrations in free-living adults-a Brazilian community-based study. Inflammation 2013;36(1):15-25

29 Mora S, Cook N, Buring JE, Ridker PM, Lee IM. Physical activity and reduced risk of cardiovascular events: potential mediating mechanisms. Circulation 2007;116(19):2110-2118
30 Lavoie ME, Rabasa-Lhoret R, Doucet E, et al. Association between physical activity energy expenditure and inflammatory markers in sedentary overweight and obese women. Int J Obes 2010;34(9): 1387-1395

31 Mora S, Lee IM, Buring JE, Ridker PM. Association of physical activity and body mass index with novel and traditional cardiovascular biomarkers in women. JAMA 2006;295(12):1412-1419

32 Buyken AE, Flood V, Empson M, et al. Carbohydrate nutrition and inflammatory disease mortality in older adults. Am J Clin Nutr 2010;92(3):634-643

33 Liu S, Manson JE, Buring JE, Stampfer MJ, Willett WC, Ridker PM. Relation between a diet with a high glycemic load and plasma concentrations of high-sensitivity C-reactive protein in middleaged women. Am J Clin Nutr 2002;75(3):492-498

34 Neuhouser ML, Schwarz Y, Wang C, et al. A low-glycemic load diet reduces serum $C$-reactive protein and modestly increases adiponectin in overweight and obese adults. J Nutr 2012;142(2):369-374

35 Hu FB. Protein, body weight, and cardiovascular health. Am J Clin Nutr 2005;82(1, Suppl)242S-247S 